\section{RMD Open}

Rheumatic \&

Musculoskeletal Diseases

To cite: Seror $R$ Bowman SJ, Brito-Zeron P, et al. EULAR Sjögren's syndrome disease activity index (ESSDAI): a user guide. RMD Open 2015;1:e000022. doi:10.1136/rmdopen-2014000022

- Prepublication history for this paper is available online. To view these files please visit the journal online (http://dx.doi.org/10.1136/ rmdopen-2014-000022).

RS and SJB contributed equally.

Received 21 November 2014 Revised 10 January 2015 Accepted 18 January 2015

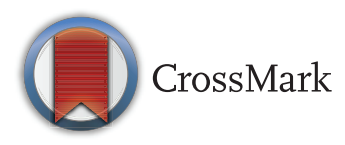

For numbered affiliations see end of article.

Correspondence to Dr Raphaèle Seror; raphaele.se@gmail.com

\title{
EULAR Sjögren's syndrome disease activity index (ESSDAI): a user guide
}

\section{Raphaèle Seror, ${ }^{1}$ Simon J Bowman, ${ }^{2}$ Pilar Brito-Zeron, ${ }^{3}$ Elke Theander, ${ }^{4}$ Hendrika Bootsma, ${ }^{5}$ Athanasios Tzioufas, ${ }^{6}$ Jacques-Eric Gottenberg, ${ }^{7}$ Manel Ramos-Casals, ${ }^{3}$ Thomas Dörner, ${ }^{8}$ Philippe Ravaud, ${ }^{9,10}$ Claudio Vitali, ${ }^{11}$ Xavier Mariette, ${ }^{1}$ on behalf of the EULAR Sjögren's Task Force}

\section{ABSTRACT}

The EULAR Sjögren's syndrome (SS) disease activity index (ESSDAI) is a systemic disease activity index that was designed to measure disease activity in patients with primary SS. With the growing use of the ESSDAI, some domains appear to be more challenging to rate than others. The ESSDAI is now in use as a gold standard to measure disease activity in clinical studies, and as an outcome measure, even a primary outcome measure, in current randomised clinical trials. Therefore, ensuring an accurate and reproducible rating of each domain, by providing a more detailed definition of each domain, has emerged as an urgent need. The purpose of the present article is to provide a user guide for the ESSDAI. This guide provides definitions and precisions on the rating of each domain. It also includes some minor improvement of the score to integrate advance in knowledge of disease manifestations. This user guide may help clinicians to use the ESSDAI, and increase the reliability of rating and consequently of the ability to detect true changes over time. This better appraisal of ESSDAI items, along with the recent definition of disease activity levels and minimal clinically important change, will improve the assessment of patients with primary SS and facilitate the demonstration of effectiveness of treatment for patients with primary SS.

\section{INTRODUCTION}

With the growing interest in conducting clinical trials in primary Sjögren's syndrome (SS), having specific and valid outcome measures became a necessity. For that purpose, an international collaboration was set up to develop and validate the EULAR Sjögren's syndrome disease activity index (ESSDAI) ${ }^{1}$ and EULAR Sjögren's syndrome patient reported index (ESSPRI). ${ }^{2}$

The ESSDAI is a systemic disease activity index that was generated in 2009. This score has been developed by consensus of a large group of worldwide experts from European and North American countries, supported by the EULAR (project code CLI 010). ${ }^{1}$ It includes 12 domains (ie, organ systems: cutaneous, respiratory, renal, articular, muscular,

\section{Key messages}

The EULAR Sjögren's syndrome (SS) disease activity index (ESSDAI) is a clinical index that measures disease activity in primary Sjögren's syndrome.

- ESSDAI is validated and used in most clinical studies and ongoing randomised controlled trials.

- This glossary provides detailed definitions of each item; useful in clinical trials to ensure reliability.

peripheral nervous system (PNS), central nervous system (CNS), haematological, glandular, constitutional, lymphadenopathic, biological). The ESSDAI includes organ-byorgan definitions that were agreed on by a large number of experts. Each domain is divided into 3-4 levels of activity. Definition of each activity level is provided by a detailed description of what should be considered in that item. The aim was to obtain a standardised instrument for the homogenous evaluation of systemic activity in order for the ESSDAI to be used as outcome criteria to evaluate primary SS in clinical trials as well as daily practice.

This tool has been validated in a large independent cohort and has been shown to have a high content validity, to be highly reproducible and to be able to detect change. ${ }^{3} 4$

In the past few years, the use of this tool has become more and more prevalent, ${ }^{5-7}$ particularly in the context of randomised controlled trials (RCTs). ${ }^{8-10}$ With the growing use of the ESSDAI, some domains appeared to be more challenging to rate than others. In the context of an RCT, ensuring a more accurate and reproducible rating of each domain, by providing a more detailed definition of each domain, emerged as an urgent need. The purpose of the present article is to provide a user guide for clinicians who use the ESSDAI to help them to measure disease activity and to ensure the best accuracy of this measure for its use in RCTs as well as in clinical practice. For 
each of the ESSDAI domains, we will focus on the potentially difficult items.

\section{METHODS}

This glossary results from an initiative of the steering committee of the EULAR Sjögren's task force collaborative group (project code CLI 010). This group of 10 physician experts in SS (HB, SJB, TD, J-EG, XM, MR-C, RS, ET, AT and $\mathrm{CV}$ ) and a clinical epidemiologist (PR), has led the development of the ESSDAI. To develop the ESSDAI, we also contacted one collaborator of a member of the steering committee (SC) who has vast experience in the use of the ESSDAI in the clinical and research setting (PB-Z).

Based on their experience in the use of the ESSDAI, three members of the SC (SJB, XM and RS) identified difficulties in rating ESSDAI items. They prepared a draft for a glossary that aimed to clarify these difficult ratings. This proposal was submitted to other experts of the SC. They were asked to suggest any changes they wanted made. Their suggestions were submitted for the approval of all the SC members by email. The modifications were integrated until all members of the SC agreed on a final version.

\section{ESSDAI domains glossary}

First, two important points have been emphasised by the SC to be considered by physicians who use the ESSDAI:

1. The ESSDAI has been developed for patients with primary SS. Therefore, other differential diagnoses should be ruled out. When the ESSDAI is used, it should be with the assurance that the signs and symptoms are related to primary SS and not to an underlying and/or associated disease. Likewise, patients with primary SS may have concomitant illnesses that can mimic SS symptoms and organ involvement, which should be taken into account.

2. When assessing disease activity of an individual patient, the physician has to keep in mind that he/ she has to exclude damage features that are irreversible. Therefore, for each single domain, the longlasting fixed features (stable for at least 12 months) should be scored as 0 .

\section{Constitutional domain}

\begin{tabular}{|c|c|c|}
\hline Domain & $\begin{array}{l}\text { Activity } \\
\text { level }\end{array}$ & Description \\
\hline \multirow{3}{*}{$\begin{array}{l}\text { Constitutional } \\
\text { Exclusion of fever of } \\
\text { infectious origin and } \\
\text { voluntary weight loss }\end{array}$} & $\mathrm{No}=0$ & $\begin{array}{l}\text { Absence of the following } \\
\text { symptoms }\end{array}$ \\
\hline & Low $=3$ & $\begin{array}{l}\text { Mild or intermittent fever } \\
\left(37.5-38.5^{\circ} \mathrm{C}\right) / \text { night sweats } \\
\text { and/or involuntary weight } \\
\text { loss of } 5-10 \% \text { of body } \\
\text { weight }\end{array}$ \\
\hline & Moderate $=6$ & $\begin{array}{l}\text { Severe fever }\left(>38.5^{\circ} \mathrm{C}\right) / \\
\text { night sweats and/or } \\
\text { involuntary weight loss of } \\
>10 \% \text { of body weight }\end{array}$ \\
\hline
\end{tabular}

The rating of this domain should take into account the following comments:

Fever and night sweats: The presence of fever (measured by the patient or the physician using a thermometer) and night sweats is based on patient responses following direct questioning 'Have you had fevers or night sweats in the past 4 weeks?'

If the fever is regularly (at least twice a week) $>38.5^{\circ} \mathrm{C}$ or if the night sweats wet the nightclothes, score as moderate activity, else in presence of milder constitutional symptoms score as low activity.

Symptoms that are thought to be due to causes other than SS, for example, menopause, concomitant infection or neoplasia, should be scored as 0 .

Weight loss: Weight loss should be recent to be taken into account (within the past 12 weeks). Where the weight loss is intentional or due to a concomitant illness, it should be scored as 0 .

Constitutional symptoms related to lymphoma should be scored in the constitutional domain in addition to the scoring of lymphoma.

\section{Lymphadenopathy and lymphoma domain}

\begin{tabular}{|c|c|c|}
\hline Domain & $\begin{array}{l}\text { Activity } \\
\text { level }\end{array}$ & Description \\
\hline \multirow{4}{*}{$\begin{array}{l}\text { Lymphadenopathy } \\
\text { and lymphoma } \\
\text { Exclusion of } \\
\text { infection }\end{array}$} & $\mathrm{No}=0$ & $\begin{array}{l}\text { Absence of the } \\
\text { following features }\end{array}$ \\
\hline & LoW $=4$ & $\begin{array}{l}\text { Lymphadenopathy } \\
\geq 1 \mathrm{~cm} \text { in any nodal } \\
\text { region or } \geq 2 \mathrm{~cm} \text { in } \\
\text { inguinal region }\end{array}$ \\
\hline & Moderate $=8$ & $\begin{array}{l}\text { Lymphadenopathy } \\
\geq 2 \mathrm{~cm} \text { in any nodal } \\
\text { region or } \geq 3 \mathrm{~cm} \text { in } \\
\text { inguinal region, and/ } \\
\text { or splenomegaly } \\
\text { (clinically palpable or } \\
\text { assessed by imaging) }\end{array}$ \\
\hline & High=12 & $\begin{array}{l}\text { Current malignant } \\
\text { B-cell proliferative } \\
\text { disorder }\end{array}$ \\
\hline
\end{tabular}

To be clearer, we added 'and lymphoma' in the title of the domain.

The rating of this domain should take in account the following comments:

Lymphadenopathy or splenomegaly: If there is no significant lymph node or splenomegaly at the clinical examination, no other examination is requested. If there are some clinical abnormalities, and if an ultrasound or CT scan has been performed, these data will be used for scoring, else clinical abnormalities should be used for scoring.

Lymphadenopathies that are thought to be due to causes other than SS, for example, to a concomitant infection, should be scored as 0 . 
Current B-cell malignant proliferative disorder. B-cell proliferative disorders are based on the WHO classification criteria 2011, including under the item 'Mature B-cell neoplasms' of this classification. ${ }^{11}$

Any B-cell malignant disorder should be taken into account except if it is in complete remission for more than 6 months after the end of the treatment (including consolidation treatment).

Thus, recently diagnosed, currently treated, untreated smouldering low-grade lymphoma, or previously treated but not in remission B-cell proliferative disorders, should be taken into account.

The history of treated lymphoma considered in remission, monoclonal gammapathy of undetermined significance should not be scored.

Multiple myeloma is not to be taken into account.

\section{Glandular domain}

\begin{tabular}{|c|c|c|}
\hline Domain & $\begin{array}{l}\text { Activity } \\
\text { level }\end{array}$ & Description \\
\hline \multirow{3}{*}{$\begin{array}{l}\text { Glandular } \\
\text { Exclusion of } \\
\text { stone or } \\
\text { infection }\end{array}$} & $\mathrm{No}=0$ & $\begin{array}{l}\text { Absence of glandular } \\
\text { swelling }\end{array}$ \\
\hline & Low $=2$ & $\begin{array}{l}\text { Small glandular swelling } \\
\text { with enlarged parotid } \\
(\leq 3 \mathrm{~cm}) \text {, or limited } \\
\text { submandibular }(\leq 2 \mathrm{~cm}) \text { or } \\
\text { lachrymal swelling } \\
(\leq 1 \mathrm{~cm})\end{array}$ \\
\hline & Moderate $=4$ & $\begin{array}{l}\text { Major glandular swelling } \\
\text { with enlarged parotid } \\
(>3 \mathrm{~cm}) \text {, or important } \\
\text { submandibular }(>2 \mathrm{~cm}) \text { or } \\
\text { lachrymal swelling }(>1 \mathrm{~cm})\end{array}$ \\
\hline
\end{tabular}

The rating of this domain should take into account the following comments.

The importance of parotid, submandibular or lachrymal gland swelling should be assessed by clinical examination and not by ultrasound. Ultrasound is a very interesting examination for assessing the structure of the gland and could be very useful for the diagnosis of SS, but until now it has not been shown to be reliable for assessing the size of the glands.

The swelling of submandibular is considered limited when it is $<2 \mathrm{~cm}$ and important when it is $>2 \mathrm{~cm}$ at its wider diameter.

The swelling of lachrymal glands is considered limited when it is $<1 \mathrm{~cm}$ and important when it is $>1 \mathrm{~cm}$ at its wider diameter.

In case of gland enlargement due only to lymphoma, lymphoma will be scored in the 'Lymphadenopathy and lymphoma' domain but not in the glandular domain. If the gland is enlarged independently from lymphoma, or if the contralateral gland or other salivary glands are enlarged, both domains should be scored.
Symptoms that are thought to be due to causes other than SS, for example, to sarcoidosis, IgG4-related disease, stones or a concomitant infection, should be scored as 0 .

\section{Articular domain}

\begin{tabular}{lll}
\hline Domain & $\begin{array}{l}\text { Activity } \\
\text { level }\end{array}$ & Description \\
\hline $\begin{array}{l}\text { Articular } \\
\begin{array}{l}\text { Exclusion of } \\
\text { osteoarthritis }\end{array}\end{array}$ & $\mathrm{No}=0$ & $\begin{array}{l}\text { Absence of currently active } \\
\text { articular involvement }\end{array}$ \\
& Arthralgias in hands, wrists, \\
& Moderate=4 & $\begin{array}{l}\text { by morning stiffness (>30 min) } \\
1-5 \text { (of } 28 \text { total count) } \\
\text { synovitis } \\
\geq 6 \text { (of } 28 \text { total count) synovitis }\end{array}$ \\
& High=6 &
\end{tabular}

The rating of this domain should take into account the following comments:

Arthralgia is a symptom characterised by joint pain without inflammatory signs in the joint/s involved. Only arthralgias of inflammatory origin should be scored. This means a positive response to both the following questions is required: "Have you got pain in your hands/ wrists/ankles and/or feet in the past 4 weeks? Are you stiff in the morning for at least 30 minutes?"

The synovitis count should be based on the 28 joint count used for the DAS28 evaluation in rheumatoid arthritis. $^{12}$ It is based on clinical examination by a medical professional or, if clinical examination is not felt to be accurate (eg, a patient with generally swollen hands where a definitive joint count is not possible), on US examination.

Arthralgias or synovitis due to other causes, such as osteoarthritis, infectious, metabolic, rheumatoid arthritis or other autoimmune diseases should be excluded.

\section{Cutaneous domain}

\begin{tabular}{|c|c|c|}
\hline Domain & $\begin{array}{l}\text { Activity } \\
\text { level }\end{array}$ & Description \\
\hline \multirow{4}{*}{$\begin{array}{l}\text { Cutaneous } \\
\text { Rate as 'No } \\
\text { activity' stable } \\
\text { long-lasting } \\
\text { features related } \\
\text { to damage }\end{array}$} & $\mathrm{No}=0$ & $\begin{array}{l}\text { Absence of currently } \\
\text { active cutaneous } \\
\text { involvement }\end{array}$ \\
\hline & $L o w=3$ & Erythema multiforma \\
\hline & Moderate $=6$ & $\begin{array}{l}\text { Limited cutaneous } \\
\text { vasculitis, including } \\
\text { urticarial vasculitis, or } \\
\text { purpura limited to feet } \\
\text { and ankle, or subacute } \\
\text { cutaneous lupus }\end{array}$ \\
\hline & High $=9$ & $\begin{array}{l}\text { Diffuse cutaneous } \\
\text { vasculitis, including } \\
\text { urticarial vasculitis, or } \\
\text { diffuse purpura, or ulcers } \\
\text { related to vasculitis }\end{array}$ \\
\hline
\end{tabular}


The rating of this domain should take into account the following comments:

Erythema multiforma: are typical targets, or raised, oedematous papules distributed acrally; involvement of mucous membranes is possible.

Subacute cutaneous lupus erythematosus (SCLE) is characterised by two forms, including papulosquamous lesions and annular lesions that develop in sun-exposed areas, including the upper back, shoulders, extensor arms, neck and upper torso, while the face is usually spared.

Cutaneous vasculitis should include purpura, maculopapular rash or urticarial rash. Lesions other than purpura and supposedly due to vasculitis such as isolated urticarial or macular rash of vasculitic origin should be confirmed (by histology and/or the presence of cryoglobulins) at least once in patient history.

Cutaneous vasculitic activity is classified according to the cutaneous extension as moderate activity (if limited to $<18 \%$ of the body surface area) or high activity (if extended to $\geq 18 \%$ of the body surface area or if showing presence of ulcers). The body surface area involved is evaluated according to figure 1 .

If a skin biopsy has been performed this should be used. Otherwise, scoring is based on clinical examination by a medical professional with suitable training and experience.

Cutaneous rash due to infections, drug reaction or neoplasia should be excluded. In case of SCLE, underlying SLE should be excluded.

\section{Pulmonary domain}

\begin{tabular}{|c|c|c|}
\hline Domain & $\begin{array}{l}\text { Activity } \\
\text { level }\end{array}$ & Description \\
\hline $\begin{array}{l}\text { Pulmonary } \\
\text { Rate as 'No } \\
\text { activity' stable } \\
\text { long-lasting } \\
\text { features } \\
\text { related to } \\
\text { damage, or } \\
\text { respiratory } \\
\text { involvement } \\
\text { not related to } \\
\text { the disease } \\
\text { (tobacco use, } \\
\text { etc) }\end{array}$ & Moderate $=10$ & 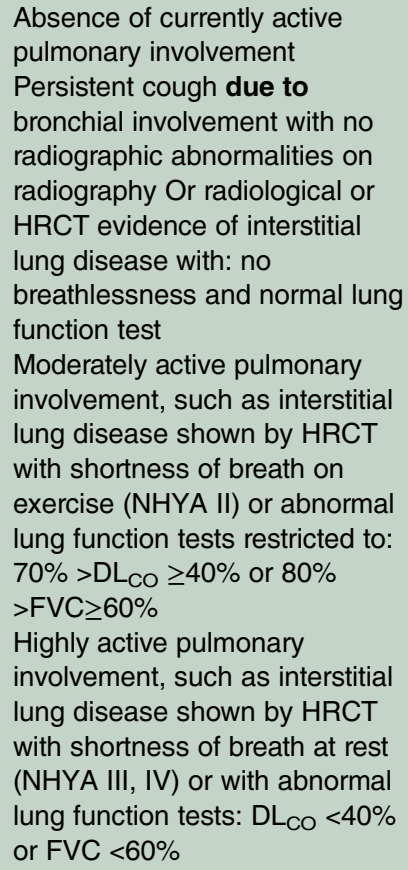 \\
\hline
\end{tabular}

FVC, forced vital capacity; HRCT, high-resolution CT; NYHA, New York Heart Association.

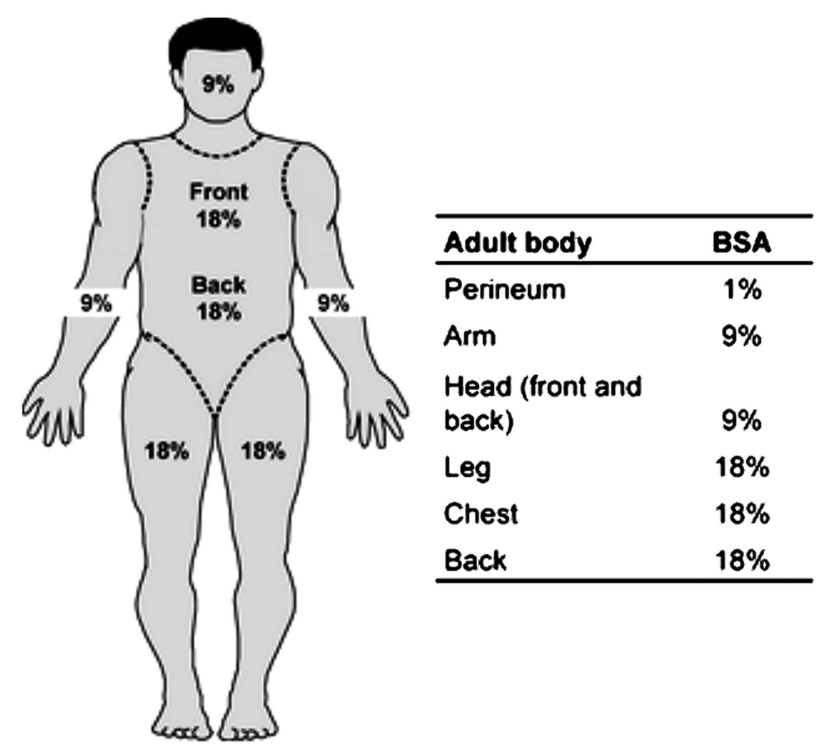

Figure 1 Body surface area.

The rating of this domain should take into account the following comments:

A persistent cough is scored if linked to bronchial involvement ascertained by either HRCT (bronchial thickening or dilation) or pulmonary function tests (PFTs) (obstructive syndrome) and not due to active infection or tobacco use. Long-lasting (more than (12 months) persistent but stable cough more likely due to damage than activity should be scored as 0 . Persistent cough only due to bronchial dryness should be scored as 0 .

To be more precise and clear we modified the wording of the low disease activity level and changed 'or' by 'due to' bronchial involvement.

Interstitial lung disease, if suspected, should have been ascertained at least once in the patient history by HRCT by the presence of mainly ground glass aspect (rather than honeycombing aspects). HRCT should be repeated if symptoms, or radiological or lung function test worsening has occurred. For follow-up, classification is made either on lung function test and/or shortness of breath.

Shortness of breath resulting in slight limitation of physical activity: patient being comfortable at rest, but for whom ordinary physical activity results in fatigue, palpitation or dyspnoea, is classified as NYHA stage II and is scored as moderate activity. If limitation is more marked with symptoms present for ordinary activity and/or at rest (NYHA III or IV), activity is scored as high.

Shortness of breath due to another cause, such as tobacco-related chronic bronchitis, cardiac insufficiency, arterial pulmonary embolism or infection) should be scored as 0 . Also, other autoimmune diseases associated with interstitial lung disease should have been excluded.

Non-evolving long-lasting (more than 12 months) interstitial lung disease thought to be due to damage rather than activity should be scored as 0 . 
Renal domain

\begin{tabular}{|c|c|c|}
\hline Domain & $\begin{array}{l}\text { Activity } \\
\text { level }\end{array}$ & Description \\
\hline \multirow{4}{*}{$\begin{array}{l}\text { Renal } \\
\text { Rate as 'No } \\
\text { activity' stable } \\
\text { long-lasting } \\
\text { features related } \\
\text { to damage and } \\
\text { renal } \\
\text { involvement not } \\
\text { related to the } \\
\text { disease. } \\
\text { If biopsy has } \\
\text { been } \\
\text { performed, } \\
\text { please rate } \\
\text { activity based } \\
\text { on histological } \\
\text { features first }\end{array}$} & $\mathrm{No}=0$ & $\begin{array}{l}\text { Absence of currently active } \\
\text { renal involvement with } \\
\text { proteinuria }<0.5 \mathrm{~g} / \text { day, no } \\
\text { haematuria, no leucocyturia, } \\
\text { no acidosis or long-lasting } \\
\text { stable proteinuria due to } \\
\text { damage }\end{array}$ \\
\hline & Low $=5$ & $\begin{array}{l}\text { Evidence of mild active renal } \\
\text { involvement, limited to tubular } \\
\text { acidosis without renal failure } \\
\text { or glomerular involvement } \\
\text { with proteinuria (between } 0.5 \\
\text { and } 1 \mathrm{~g} / \text { day) and without } \\
\text { haematuria or renal failure } \\
\text { (GFR } \geq 60 \mathrm{~mL} / \mathrm{min} \text { ) }\end{array}$ \\
\hline & Moderate $=10$ & $\begin{array}{l}\text { Moderately active renal } \\
\text { involvement, such as tubular } \\
\text { acidosis with renal failure } \\
\text { (GFR }<60 \mathrm{~mL} / \mathrm{min} \text { ) or } \\
\text { glomerular involvement with } \\
\text { proteinuria between } 1 \text { and } \\
1.5 \mathrm{~g} / \text { day and without } \\
\text { haematuria or renal failure } \\
\text { (GFR } \geq 60 \mathrm{~mL} / \mathrm{min} \text { ) or } \\
\text { histological evidence of } \\
\text { extra-membranous } \\
\text { glomerulonephritis or } \\
\text { important interstitial lymphoid } \\
\text { infiltrate }\end{array}$ \\
\hline & High $=15$ & $\begin{array}{l}\text { Highly active renal } \\
\text { involvement, such as } \\
\text { glomerular involvement with } \\
\text { proteinuria }>1.5 \mathrm{~g} / \text { day, or } \\
\text { haematuria or renal failure } \\
\text { (GFR }<60 \mathrm{~mL} / \mathrm{min} \text { ), or } \\
\text { histological evidence of } \\
\text { proliferative glomerulonephritis } \\
\text { or cryoglobulinemia related } \\
\text { renal involvement }\end{array}$ \\
\hline
\end{tabular}

The rating of this domain should take into account the following comments:

If a renal biopsy has been carried out, this should be used to rate activity. If not, then proteinuria, haematuria, urinary $\mathrm{pH}$ and blood tests should be used.

Renal tubular acidosis is defined by the presence of hyperchloraemia and low serum bicarbonate level both outside the normal laboratory value.

Renal involvement that is thought to be due to causes other than SS, for example, nephro-angiosclerosis, diabetes, renal involvement associated with endocrine diseases, drugs, viral infections, haematological diseases or other systemic diseases, should be scored as 0 .

Long-lasting (more than 12 months) non-evolving renal involvement thought to be due to damage rather than activity should be scored as 0 .
Muscular domain

\begin{tabular}{|c|c|c|}
\hline Domain & $\begin{array}{l}\text { Activity } \\
\text { level }\end{array}$ & Description \\
\hline \multirow{4}{*}{$\begin{array}{l}\text { Muscular } \\
\text { Exclusion of } \\
\text { weakness due to } \\
\text { corticosteroids }\end{array}$} & $\mathrm{No}=0$ & $\begin{array}{l}\text { Absence of currently } \\
\text { active muscular } \\
\text { involvement }\end{array}$ \\
\hline & Low $=6$ & $\begin{array}{l}\text { Mild active myositis } \\
\text { shown by abnormal } \\
\text { EMG, MRI }{ }^{*} \text { or biopsy } \\
\text { with no weakness and } \\
\text { creatine kinase } \\
(\mathrm{N} \leq \mathrm{CK} \leq 2 \mathrm{~N})\end{array}$ \\
\hline & Moderate $=12$ & $\begin{array}{l}\text { Moderately active } \\
\text { myositis proven by } \\
\text { abnormal EMG, MRI }{ }^{*} \text { or } \\
\text { biopsy with weakness } \\
\text { (maximal deficit of } 4 / 5) \text {, } \\
\text { or elevated creatine } \\
\text { kinase }(2 \mathrm{~N}<\mathrm{CK} \leq 4 \mathrm{~N}) \text {, }\end{array}$ \\
\hline & High $=18$ & $\begin{array}{l}\text { Highly active myositis } \\
\text { shown by abnormal } \\
\text { EMG, MRI }{ }^{\star} \text { or biopsy } \\
\text { with weakness (deficit } \\
\leq 3 / 5 \text { ) or elevated } \\
\text { creatine kinase }(>4 N)\end{array}$ \\
\hline \multicolumn{3}{|c|}{$\begin{array}{l}\text { We decided to add this item not included in the initial version since } \\
\text { the value of this examination for the diagnosis of myositis was not } \\
\text { clear until recently. } \\
\text { EMG, electromyogram. }\end{array}$} \\
\hline
\end{tabular}

The rating of this domain should take into account the following comments:

Diagnosis of myositis should be made on the association of clinical symptoms (muscular pain or weakness) and/or CK elevation and either muscular involvement confirmed by needle detection on EMG, by diffuse inflammation on MRI and/or active myositis on biopsy. Therefore, having one positive examination among EMG, MRI or biopsy is mandatory, but all are not necessary.

EMG should be performed by an accredited neurophysiologist. MRI evidence myositis with diffuse inflammation has been added to the definition of muscular domain, due to the recognised value of this examination for that purpose. Muscle biopsy is not mandatory in the definition of the activity levels of the domain, but advised in case of uncertainty on the diagnosis. A new biopsy is not mandatory in case of recurrence of the same symptoms with creatine kinase elevation and a previous biopsy showing inflammatory myositis.

Patients having only muscular pain but no muscle weakness and normal creatine kinase level should be scored as low activity; active myositis is proven either by abnormal EMG, MRI or biopsy.

Non-autoimmune causes (infection, statins and other drugs or toxics, etc) should be excluded. Muscle weakness or involvement that is thought to be due to causes other than SS, such as fibromyalgia, corticosteroids, statins or other classified auto-immune disease should be scored as 0 . 
PNS domain

\begin{tabular}{|c|c|c|}
\hline Domain & $\begin{array}{l}\text { Activity } \\
\text { level }\end{array}$ & Description \\
\hline $\begin{array}{l}\text { PNS } \\
\text { Rate as 'No } \\
\text { activity' stable } \\
\text { long-lasting } \\
\text { features related } \\
\text { to damage or } \\
\text { PNS } \\
\text { involvement not } \\
\text { related to the } \\
\text { disease }\end{array}$ & $\begin{array}{l}\mathrm{No}=0 \\
\text { Low }=5\end{array}$ & 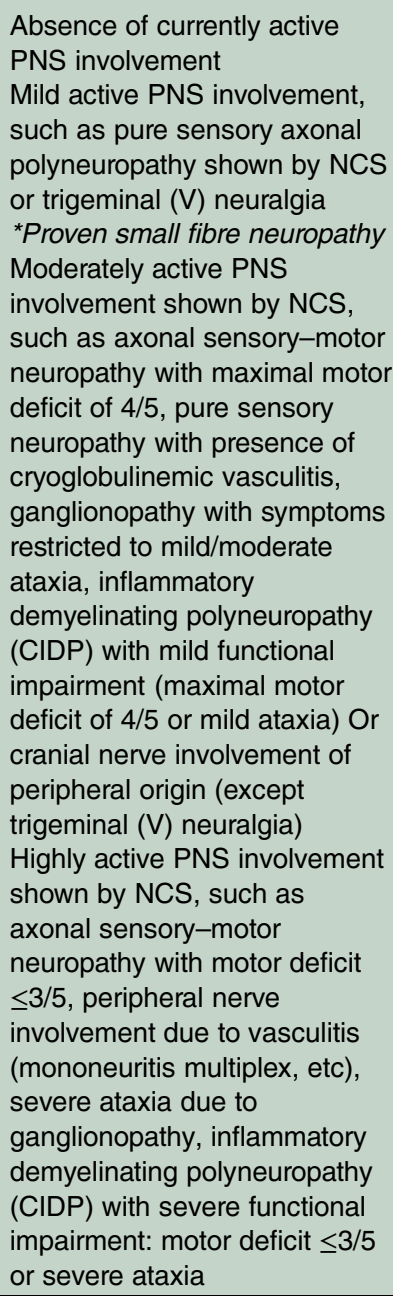 \\
\hline
\end{tabular}

${ }^{*}$ We decided to add this item not included in the initial version since the link between this entity and SS was not clear until recently. CIPD, chronic inflammatory demyelinating polyneuropathy; NCS, nerve conduction study.

The rating of this domain should take into account the following comments:

For all peripheral neuropathy (except cranial nerve neuropathy and small fibre neuropathy), peripheral neurological involvement should have been ascertained by NCS at least once. The diagnosis of patients with peripheral neuropathy requires exhaustive evaluation of signs and symptoms, followed by confirmation by electrodiagnostic studies, which are useful in establishing the type of neuropathy and whether it is primarily demyelinating or axonal.

Some types of neuropathy may require additional diagnostic tests:

- Proximal demyelinating neuropathy: elevated cerebrospinal fluid protein level and/or sensory evoked potentials.

- Small fibre neuropathy should have been ascertained by a cutaneous biopsy, and/or altered or absent laser-evoked potentials and/or abnormal quantitative sensory testing to thermal stimuli and/or abnormal sympathetic sensory testing.

For muscular testing, grade $3 / 5$ means that the patient holds test position against gravity with no added pressure, but not against external pressure. If the motor deficit is grade 3 or less, activity should be scored as high.

Peripheral neuropathy that is thought to be due to causes other than SS, such as diabetes, or due to metabolic or toxic causes, or that are inherited, should be scored as 0 .

Long-lasting (more than 12 months) non-evolving neurological involvement thought to be due to damage rather than activity should be scored as 0 .

\section{Central nervous system domain}

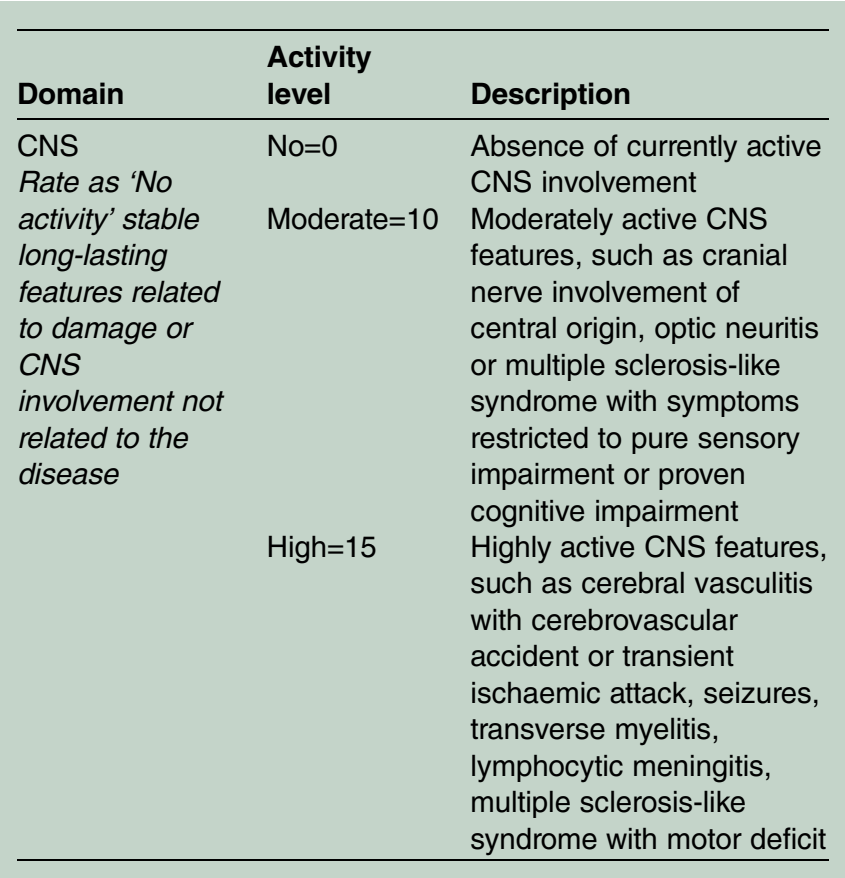

The rating of this domain should take into account the following comments:

CNS events (except lymphocytic meningitis) must be supported by abnormalities on MRI able to explain the symptoms presented by the patient, and different from what could be observed in a same age subject, according to an experienced neuroradiologist or neurologist. Optic neuritis should be confirmed either by visual-evoked potentials or MRI. Cerebrovascular events or white matter lesions that are likely due to atherosclerosis or cardiac embolism, infectious disease, or other autoimmune disease, should be scored as 0 .

In case of a certain diagnosis of MS by an experienced neurologist or fulfilment of the 2010 McDonald MS diagnostic criteria, ${ }^{13}$ involvement should be considered as MS and should not be scored in the ESSDAI.

Long-lasting (more than 12 months) non-evolving neurological involvement thought to be due to damage rather than activity should be scored as 0 . 
Haematological domain

\begin{tabular}{|c|c|c|}
\hline Domain & $\begin{array}{l}\text { Activity } \\
\text { level }\end{array}$ & Description \\
\hline $\begin{array}{l}\text { Haematological } \\
\text { For anaemia, } \\
\text { neutropenia, } \\
\text { and } \\
\text { thrombopenia, } \\
\text { only } \\
\text { auto-immune } \\
\text { cytopenia must } \\
\text { be considered } \\
\text { Exclusion of } \\
\text { vitamin or iron } \\
\text { deficiency, } \\
\text { drug-induced } \\
\text { cytopenia }\end{array}$ & Moderate $=4$ & 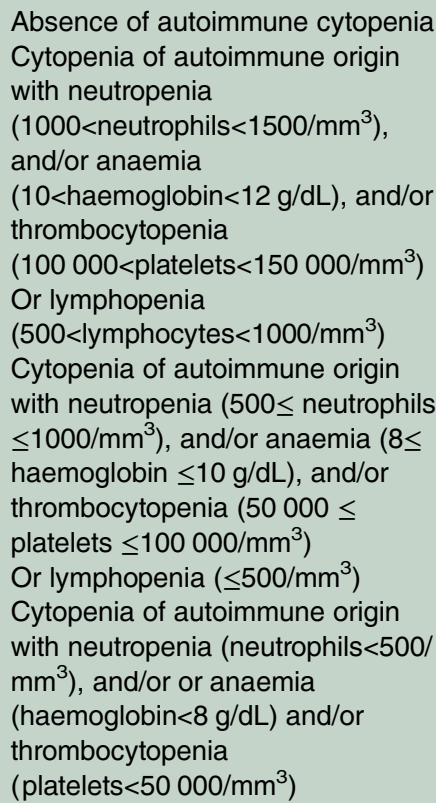 \\
\hline
\end{tabular}

The rating of this domain should take into account the following comments:

Cytopenias that are thought to be due to causes other than SS should be scored as 0 .

- Cytopenia due to drug-induced toxicity, viral infections or haematological disorder other than autoimmunity or lymphoma;

- Anaemia due to iron or vitamin deficiency;

- Neutropenia of ethnic origin or due to drug associated agranulocytosis;

- Thrombocytopenia linked to hypersplenism.

Other causes of autoimmune cytopenia should have been discarded.

\section{Biological domain}

\begin{tabular}{lll}
\hline Domain & $\begin{array}{l}\text { Activity } \\
\text { level }\end{array}$ & Description \\
\hline Biological & $\mathrm{No}=0$ & $\begin{array}{l}\text { Absence of any of the following } \\
\text { biological feature } \\
\text { Clonal component and/or } \\
\text { hypocomplementemia (low C4 or } \\
\text { C3 or CH50) and/or } \\
\text { hypergammaglobulinemia or high } \\
\text { IgG level between } 16 \text { and } 20 \mathrm{~g} / \mathrm{L}\end{array}$ \\
& $\begin{array}{l}\text { Presence of cryoglobulinemia and/ } \\
\text { or hypergammaglobulinemia or } \\
\text { high lgG level }>20 \mathrm{~g} / \mathrm{L}, \text { and/or } \\
\text { recent onset } \\
\text { hypogammaglobulinemia or recent } \\
\text { decrease of IgG level }(<5 \mathrm{~g} / \mathrm{L})\end{array}$ \\
\hline
\end{tabular}

The rating of this domain should take into account the following comments:

If both IgG and gammaglobulin levels are available, take the highest value and continue to use the same test in the same patient for longitudinal examination.

A clonal component can be detected by serum electrophoresis, serum or urine immunofixation or by an abnormal ratio of free light chains in the serum.

The biological presence of cryoglobulinemia should be taken into account even if there is no clinical sign, even in the case of low cryocrit levels $(<1 \%)$. Clinical signs related to cryoglobulinemia should be additionally scored in each domain.

\section{CONCLUSION}

Since its development, the ESSDAI has been frequently used in primary SS clinical studies. The ESSDAI is now in use as a gold standard, as the SLEDAI or BILAG is in lupus, ${ }^{1415}$ to measure systemic disease activity in clinical and biological studies in SS that aim at evaluating new biomarkers of activity. ${ }^{16-19}$ It has been shown to correlate with B-cell biomarkers such as $\beta 2$ microglobulin, serum free light chains of immunoglobulins, ${ }^{5}{ }^{20}$ the cytokine $\mathrm{BAFF}^{6}$ and to be associated with the risk of lymphoma. ${ }^{6} 21$

In addition, ESSDAI has started to be used as an outcome measure in RCTs in SS, and even as the primary outcome measure in currently ongoing RCTs. Recently, the definition of disease activity levels and thresholds of minimal clinically important improvement (MCII) have been recently proposed for that tool: a moderately active disease being defined as an ESSDAI $\geq 5$ and an MCII as a decrease of at least 3 points. ${ }^{22}$ These cut-offs have started to be used, respectively, as entry criteria and primary end points for RCTs (testing tocilizumab [NCT01782235] or abatacept [NCT02067910]). In this setting, enhancing the accuracy and the reliability of disease activity scoring to correctly classify patients at study entry but also at final evaluation is a crucial point to determine the efficacy of the drug under investigation.

Finally, the detailed definitions given in this paper on the way to rate each of the ESSDAI domains will be useful in future RCTs as well as in clinical practice. We hope it will improve the accuracy of clinical trials data and help to demonstrate the effectiveness of future treatment in patients with primary SS.

\section{Author affiliations}

${ }^{1}$ Department of Rheumatology, Hôpitaux Universitaires Paris-Sud, Assistance Publique-Hopitaux de Paris, Université Paris-Sud, INSERM U1012, Le Kremlin Bicêtre, France

${ }^{2}$ Rheumatology Department, University Hospitals Birmingham NHS Foundation Trust, Birmingham, UK

${ }^{3}$ Laboratory of Autoimmune Diseases "Josep Font”, CELLEX-IDIBAPS, Department of Autoimmune Diseases, ICMiD, Hospital Clinic, Barcelona, Spain

${ }^{4}$ Department of Rheumatology, Skane University Hospital Malmö, Lund University, Malmo, Sweden 
${ }^{5}$ Department of Rheumatology and Clinical Immunology, University of Groningen, University Medical Center Groningen, Groningen, The Netherlands ${ }^{6}$ Department of Pathophysiology, School of Medicine, University of Athens, Athens, Greece

${ }^{7}$ Rheumatology, Centre National de Référence des Maladies Auto-Immunes Rares, INSERM UMRS_1109, Fédération de Médecine Translationnelle de Strasbourg (FMTS), Strasbourg University Hospital, Université de Strasbourg, Strasbourg, France

${ }^{8}$ Rheumatology Department, Charité, University Hospital, Berlin, Germany ${ }^{9}$ Center of Clinical Epidemiology, Hôpital Hôtel Dieu, Paris, France ${ }^{10}$ INSERM U738, Université Paris-René Descartes, Paris, France

${ }^{11}$ Sections of Rheumatology, Instituto San Giuseppe, Como and Casa di Cura di Lecco, Lecco, Italy

Acknowledgements The authors would like to thank the patients with pSS included in the EULAR cohort; the EULAR for its grant to the project; Prs Maxime Dougados, Alan Tyndall, Daniel Aletaha and Désirée van der Heijde for their guidance and support; the EULAR house in Zurich for their hospitality and outstanding organisation (Ernst Isler and his associates). They also thank all the Sjögren's patients who take part in this project.

Collaborators Members of the EULAR Sjögren's Task Force-Karsten Asmussen and Soren Jacobsen, Department of Rheumatology, University Hospital, Copenhagen, Denmark; Elena Bartoloni and Roberto Gerli, Rheumatology Unit, Department of Clinical \& Experimental Medicine, University of Perugia, Italy; Johannes WJ Bijlsma and Aike A Kruize, Department of Rheumatology \& Clinical Immunology, University Medical Center, Utrecht, the Netherlands; Stefano Bombardieri, Rheumatology Unit, Department of Internal Medicine, University of Pisa, Pisa, Italy; Arthur Bookman, Division of Rheumatology, University of Toronto, Ontario, Canada; $\mathrm{HB}$, Cees Kallenberg and Petra Meiners, Department of Rheumatology and Clinical Immunology, University Medical Center, Groningen, the Netherlands; SJB, Rheumatology Department, University Hospital, Birmingham, UK; Johan G Brun and Roland Jonsson, Department of Rheumatology, Haukeland University Hospital, Bergen, Norway; Roberto Caporali, Department of Rheumatology, University of Pavia, IRCCS S Matteo Foundation, Pavia, Italy; Steven Carsons, Division of Rheumatology, Allergy and Immunology, Winthrop University Hospital, Mineola, USA; Salvatore De Vita, Clinic of Rheumatology, University Hospital, Udine, Italy; Nicoletta Del Papa, Department of Rheumatology, G Pini Hospital, Milano, Italy; Valerie Devauchelle and Alain Saraux, Rheumatology Department, la Cavale Blanche Teaching Hospital, Brest, France; TD, Rheumatology Department, Charité, University Hospital, Berlin, Germany; Anne-Laure Fauchais, Department of Rheumatology, University Hospital, Limoges, France; J-EG, Jean Sibilia, Department of Rheumatology, University Hospital, Strasbourg, France; Eric Hachulla, Department of Internal Medicine, Claude Huriez Hospital, Lille, France; Gabor Illei, Sjögren's Syndrome Clinic, National Institute of Dental and Craniofacial Research, Bethesda, USA; David Isenberg, Centre for Rheumatology, University College, London, UK; Adrian Jones, Rheumatology Unit, City Hospital, Nottingham, UK; Menelaos Manoussakis, AT, Department of Pathophysiology, School of Medicine, University of Athens, Greece; Thomas Mandl, ET and Lennart Jacobsson, Department of Rheumatology, Malmö University Hospital, Lund University, Sweden; XM, Frederic Demoulins and RS, Department of Rheumatology, Bicêtre Hospital, Le Kremlin Bicêtre, France; Carlomaurizio Montecucco, Department of Rheumatology, University of Pavia, Pavia, Italy; Wan-Fai Ng, Musculoskeletal Research Group, University of Newcastle, Newcastle, UK; Sumusu Nishiyama, Rheumatic Disease Center, Kurashiki Medical Center, Kurashiki, Japan; Roald Omdal, Department of Internal Medicine, University Hospital, Stavanger, Norway; Ann Parke, Clinical Immunology Unit, Division of Rheumatology, Saint Francis Hospital and Medical Center, Hartford, USA; Sonja Praprotnik and Matjia Tomsic, Department of Rheumatology, University Medical Centre, Ljubljana, Slovenia; Elizabeth Price, Department of Rheumatology, Great Western Hospital, Swindon, UK; MR-C, Laboratory of Autoimmune Diseases "Josep Font”, Hospital Clinic, Barcelona, Spain; PR, Department of Epidemiology, Biostatistics and Clinical Research, Bichat Hospital, Paris, France; Hal Scofield and Kathy L Sivils, Arthritis and Clinical Immunology, Oklahoma Medical Research Foundation, Oklahoma City, USA; Josef Smolen, Division of Rheumatology, Department of Internal Medicine III, Medical University, Vienna, Austria; Roser Solans Laqué, Department of Autoimmune Systemic Diseases, Vall d'Hebron University Hospital, Barcelona,
Spain; Serge Steinfeld, Department of Rheumatology, Erasme University Hospital, Brussels, Belgium; Nurhan Sutcliffe, Department of Rheumatology, Barts \& The Royal London Hospital, London, UK; Takayuki Sumida, Department of Internal Medicine, University of Tsukuba, Japan; Matjia Tomsic, Department of Rheumatology, University Medical Centre, Ljubljana, Slovenia; Athanasios Tzioufas, Department of Pathophysiology, School of Medicine, University of Athens, Greece; Guido Valesini, Rheumatology Unit, Department of Clinical \& Experimental Medicine, Sapienza University of Rome, Rome, Italy; Valeria Valim, Division of Rheumatology, Department of Medicine, Federal University of Espírito Santo, Brazil; Frederick B Vivino, Department of Rheumatology, Penn Presbyterian Medical Center, University of Pennsylvania, Philadelphia, USA; CV, Department of Internal Medicine and Section of Rheumatology, "Villamarina" Hospital, Piombino, Italy; Frederick B Vivino, Department of Rheumatology, Penn Presbyterian Medical Center, University of Pennsylvania, Philadelphia, USA; Cristina Vollenweider, Department of Rheumatology, German Hospital, Buenos-Aires, Argentina.

Contributors RS, SB and XM were responsible for conception and design. All authors interpreted the data, drafted the article or revised it critically for important intellectual content. All authors gave final approval of the published version.

\section{Competing interests None.}

Provenance and peer review Not commissioned; externally peer reviewed.

Data sharing statement No additional data are available.

Open Access This is an Open Access article distributed in accordance with the Creative Commons Attribution Non Commercial (CC BY-NC 4.0) license, which permits others to distribute, remix, adapt, build upon this work noncommercially, and license their derivative works on different terms, provided the original work is properly cited and the use is non-commercial. See: http:// creativecommons.org/licenses/by-nc/4.0/

\section{REFERENCES}

1. Seror R, Ravaud P, Bowman SJ, et al. EULAR Sjogren's syndrome disease activity index: development of a consensus systemic disease activity index for primary Sjogren's syndrome. Ann Rheum Dis 2010;69:1103-9.

2. Seror R, Ravaud P, Mariette X, et al; EULAR Sjögren's Task Force. EULAR Sjogren's Syndrome Patient Reported Index (ESSPRI): development of a consensus patient index for primary Sjogren's syndrome. Ann Rheum Dis 2011;70:968-72.

3. Seror R, Mariette X, Bowman S, et al. Accurate detection of changes in disease activity in primary Sjogren's syndrome by the European League Against Rheumatism Sjogren's Syndrome Disease Activity Index. Arthritis Care Res (Hoboken) 2010;62:551-8.

4. Seror R, Theander E, Brun JG, et al; on behalf of the EULAR Sjögren's Task Force. Validation of EULAR primary Sjogren's syndrome disease activity (ESSDAI) and patient indexes (ESSPRI). Ann Rheum Dis 2014. Published Online First.

5. Gottenberg JE, Seror R, Miceli-Richard C, et al. Serum levels of beta2-microglobulin and free light chains of immunoglobulins are associated with systemic disease activity in primary Sjogren's syndrome. Data at enrollment in the prospective ASSESS cohort. PLOS ONE 2013;8:e59868.

6. Quartuccio L, Salvin S, Fabris M, et al. BLyS upregulation in Sjogren's syndrome associated with lymphoproliferative disorders, higher ESSDAI score and B-cell clonal expansion in the salivary glands. Rheumatology (Oxford) 2013;52:276-81.

7. Ramos-Casals M, Brito-Zeron P, Solans R, et al. Systemic involvement in primary Sjogren's syndrome evaluated by the EULAR-SS disease activity index: analysis of 921 Spanish patients (GEAS-SS Registry). Rheumatology (Oxford) 2014;53:321-31.

8. Meiners $P$, Vissink A, Kroese FG, et al. Abatacept treatment reduces disease activity in early primary Sjögren's syndrome (phase II open label ASAP study). Ann Rheum Dis 2013;72:89.

9. Moerman RV, Arends S, Meiners PM, et al. EULAR Sjogren's Syndrome Disease Activity Index (ESSDAI) is sensitive to show efficacy of rituximab treatment in a randomised controlled trial. Ann Rheum Dis 2014;73:472-4.

10. Gottenberg JE, Ravaud P, Puechal X, et al. Effects of hydroxychloroquine on symptomatic improvement in primary Sjogren syndrome: the JOQUER randomized clinical trial. JAMA 2014;312:249-58. 
11. Campo E, Swerdlow SH, Harris NL, et al. The 2008 WHO classification of lymphoid neoplasms and beyond: evolving concepts and practical applications. Blood 2011;117:5019-32.

12. Prevoo ML, van 't Hof MA, Kuper $\mathrm{HH}$, et al. Modified disease activity scores that include twenty-eight-joint counts. Development and validation in a prospective longitudinal study of patients with rheumatoid arthritis. Arthritis Rheum 1995;38:44-8.

13. Polman $\mathrm{CH}$, Reingold SC, Banwell $\mathrm{B}$, et al. Diagnostic criteria for multiple sclerosis: 2010 revisions to the McDonald criteria. Ann Neurol 2011;69:292-302.

14. Bombardier C, Gladman DD, Urowitz MB, et al. Derivation of the SLEDAI. A disease activity index for lupus patients. The Committee on Prognosis Studies in SLE. Arthritis Rheum 1992;35:630-40.

15. Isenberg DA, Rahman A, Allen E, et al. BILAG 2004. Development and initial validation of an updated version of the British Isles Lupus Assessment Group's disease activity index for patients with systemic lupus erythematosus. Rheumatology (Oxford) 2005;44:902-6.

16. Theander $\mathrm{E}$, Vasaitis L, Baecklund $\mathrm{E}$, et al. Lymphoid organisation in labial salivary gland biopsies is a possible predictor for the development of malignant lymphoma in primary Sjogren's syndrome. Ann Rheum Dis 2011;70:1363-8.

17. Tobon GJ, Saraux A, Gottenberg JE, et al. Role of Fms-like tyrosine kinase 3 ligand as a potential biologic marker of lymphoma in primary Sjogren's syndrome. Arthritis Rheum 2013;65:3218-27.
18. Furuzawa-Carballeda J, Hernandez-Molina G, Lima G, et al. Peripheral regulatory cells immunophenotyping in primary Sjogren's syndrome: a cross-sectional study. Arthritis Res Ther 2013;15:R68.

19. Alunno A, Nocentini G, Bistoni O, et al. Expansion of CD4 +CD25-GITR+ regulatory T-cell subset in the peripheral blood of patients with primary Sjogren's syndrome: correlation with disease activity. Reumatismo 2012;64:293-8.

20. Pertovaara M, Korpela M. Serum beta2 microglobulin correlates with the new ESSDAl in patients with Sjogren's syndrome. Ann Rheum Dis 2011;70:2236-7.

21. Brito-Zeron P, Kostov B, Solans R, et al; on behalf of the SS Study Group, Autoimmune Diseases Study Group (GEAS), Spanish Society of Internal Medicine (SEMI). Systemic activity and mortality in primary Sjögren syndrome: predicting survival using the EULAR-SS disease activity index (ESSDAI) in 1045 patients. Ann Rheum Dis 2014. Published Online First 28 Nov 2014. doi:10.1136/ annrheumdis-2014-206418.

22. Seror R, Bootsma H, Saraux A, et al; on behalf of the EULAR Sjögren's Task Force. Defining disease activity states and clinically meaningful improvement in primary Sjogren's syndrome with EULAR primary Sjogren's syndrome disease activity (ESSDAI) and patient-reported indexes (ESSPRI). Ann Rheum Dis 2014. Published Online First 